\title{
An Endearing Epistle from A Dutch Colonial Governor to A Malay Ruler in His Dominion
}

Rozita Che Rodi, Salmah Jan Noor Muhammad

To Link this Article: http://dx.doi.org/10.6007/IJARBSS/v11-i3/8783

DOI:10.6007/IJARBSS/v11-i3/8783

Received: 26 January 2021, Revised: 23 February 2021, Accepted: 05 February 2021

Published Online: 16 March 2021

In-Text Citation: (Rodi \& Muhammad, 2021)

To Cite this Article: Rodi, R. C., \& Muhammad, S. J. N. (2021). An Endearing Epistle from A Dutch Colonial Governor to A Malay Ruler in His Dominion. International Journal of Academic Research in Business and Social Sciences, 11(3), 644-654.

Copyright: (c) 2021 The Author(s)

Published by Human Resource Management Academic Research Society (www.hrmars.com) This article is published under the Creative Commons Attribution (CC BY 4.0) license. Anyone may reproduce, distribute, translate and create derivative works of this article (for both commercial and non-commercial purposes), subject to full attribution to the original publication and authors. The full terms of this license may be seen at: http://creativecommons.org/licences/by/4.0/legalcode

Vol. 11, No. 3, 2021, Pg. 644 - 654

Full Terms \& Conditions of access and use can be found at http://hrmars.com/index.php/pages/detail/publication-ethics 


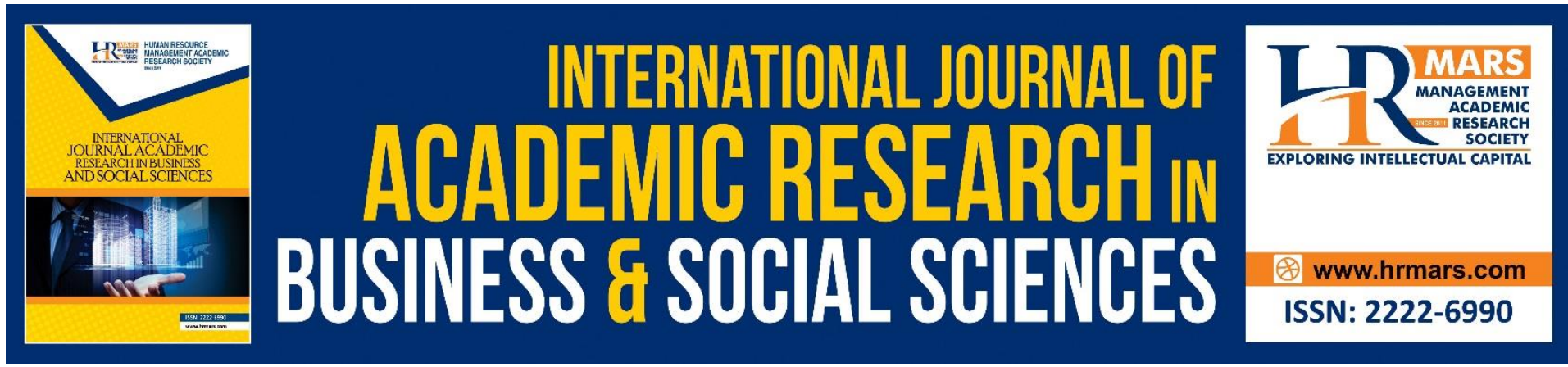

\title{
An Endearing Epistle from A Dutch Colonial Governor to A Malay Ruler in His Dominion
}

\author{
Rozita Che Rodi \\ Universiti Putra Malaysia, Malaysia \\ Salmah Jan Noor Muhammad \\ Universiti Putra Malaysia, Malaysia
}

\begin{abstract}
In this article a study is done on the National Library of Malaysia (Perpustakaan Negara Malaysia) MSS 4049 A Letter from A Dutch Colonial Governor-General in Batavia dated 1848 (MSS 4049 Surat daripada Governor General Belanda di Negeri Betawi bertarikh 1848). The study is in the forms of a transliteration, annotation and translation of the letter and also a general discussion of the historical background and content of the letter. Also a discussion on the common features of the Dutch letter with the style of the Malay rulers' letter will be made, namely the writing of a short formulaic heading on top of the page as a kind of statement, kind words of endearment and honorable words of addressing the recipients, prayer to the Almighty for the long life and good health of the addressee and the mention of the exchange of precious gifts. One feature that is in complete contrast with the etiquette of Malay rulers' letter writing was the conspicuous introduction in the opening line of the Governor-General's letter, of the status of the sender with grandeurs mentions of one's honor and awards, and also the use of plain paper without illumination by the Dutch GovernorGeneral which contrasted to the Malay rulers' letter writing style of using intricate illumination. This study also revealed that although the letter is from a Dutch colonial Governor-General to one of the Malay rulers in his dominions, the civility, mutual respect and appropriate decorum of addressing between rulers, were practiced and adopted.
\end{abstract}

Keywords: Epistles, The Ruler of Sambas, Dutch Governor-General in Batavia, Etiquettes of Letter Writing, Transliteration, Annotation.

\section{Introduction}

On 2012, April 9, we received a very interesting mail with a CD from the National Library of Malaysia (Perpustakaan Negara Malaysia) containing copies of four recently acquired manuscripts ${ }^{1}$. They are listed as follows:

\footnotetext{
${ }^{1}$ We would like to acknowledge with gratitude to the National Library of Malaysia (Perpustakaan Negara Malaysia) especially to the Deputy Director General Mdm. Nasimah Badaruddin, Senior Assistant Director Mr. Faizal Hilmie Yusof and their officers in making available these manuscripts for this study.
} 
1) MSS 4013 Surat daripada Seri Paduka Sultan Pahang kepada anakanda yang Mulia Sultan Abu Bakar Yang Dipertuan Negeri Johor bertarikh 1932, 16 Disember (1351, 17 Sya'ban). (MSS 4013 A letter from Seri Paduka Sultan of Pahang to His Highness Sultan Abu Bakar of Johore dated 1932, December 16 (1351, Sya'ban 17).

2) MSS 4049 Surat daripada Governor General Belanda di Negeri Betawi bertarikh 1834, 27 Februari (tarikh sebenar 1848, Rabi ul Akhir 1264). (MS 4049 A letter from A Dutch Colonial Governor-General in Batavia dated 1834, February 27 (actual date was 1848, Rabi 'ul Akhir 1264).

3) MSS 4160 Surat perjanjian peraturan meminjam tanah. (MSS $4160 \mathrm{~A}$ letter on the Agreement of land mortgage).

4) MSS 4270 Salasilah Kerajaan Sambas (MSS 4270 A history of Sambas Kingdom).

Of the four manuscripts, two containing descriptions of very interesting episodes or reflection of events in the history of western colonization in the Malay world, namely the MSS $4049 \mathrm{~A}$ Letter from A Dutch Colonial Governor-General in Batavia dated 1848, and MSS 4160 A Letter on the Agreement of Land Mortgage.

In this article, however, only the MSS 4049 A Letter from A Dutch Colonial Governor-General in Batavia dated 1848 will be studied in the forms of a transliteration, English translation and annotation of the letter and also a general discussion of the historical background and content of the letter. The copy of the letter is appended with the paper. The MSS 4049 was acquired by the National Library of Malaysia (Perpustakaan Negara Malaysia) on 2007, April 12 from one Syarif Hud, and its source of origin was Pontianak West Kalimantan.

\section{MS 4049 A Letter from A Dutch Colonial Governor-General in Batavia to the Ruler of Sambas A Brief Historical Background}

The letter was written as a reply to an earlier letter from the ruler of Sambas. It was written by Jan Jacob Rochussen the Dutch Governor-General in Batavia, the capital of Dutch colonial government in Indonesia, in the Hijriah year of 1264 equivalent to 1848 CE (See the transliteration of the text below for the fixation of these dates). This is 24 years after the Anglo-Dutch Treaty of 1824 which stated, among other clauses, the clear demarcation of territorial dominion between the British and the Dutch, namely the Malay Peninsula including Singapore and the Northern Borneo Island were to be under the British, while the whole of Indonesian Islands including the southern half of the Borneo Island (presently known as Kalimantan) were to be under the Dutch.

However, in the 18th century before the Anglo-Dutch Treaty of 1824, the area from Sambas to Berau (see map of Kalimantan below) were tributaries of the Malay Banjar Kingdom. This eventually shrunk to the size of what is now South Kalimantan as a result of agreements with the Dutch. In the Karang Intan Agreement during the reign of Prince Nata Dilaga (Susuhunan Nata Alam) (1808-1825), the Banjar Kingdom gave up its territories to the Dutch Indies which included Bulungan, Kutai, Pasir, Pagatan and Kotawaringin. Other territories in West Kalimantan given up to the Dutch Indies were Landak, Sambas, Sintang and Sukadana. Thus, the 1824 Anglo-Dutch Treaty merely reconfirmed the status quo, as at that time, the Sambas Kingdom was already under the dominion of the Dutch. 


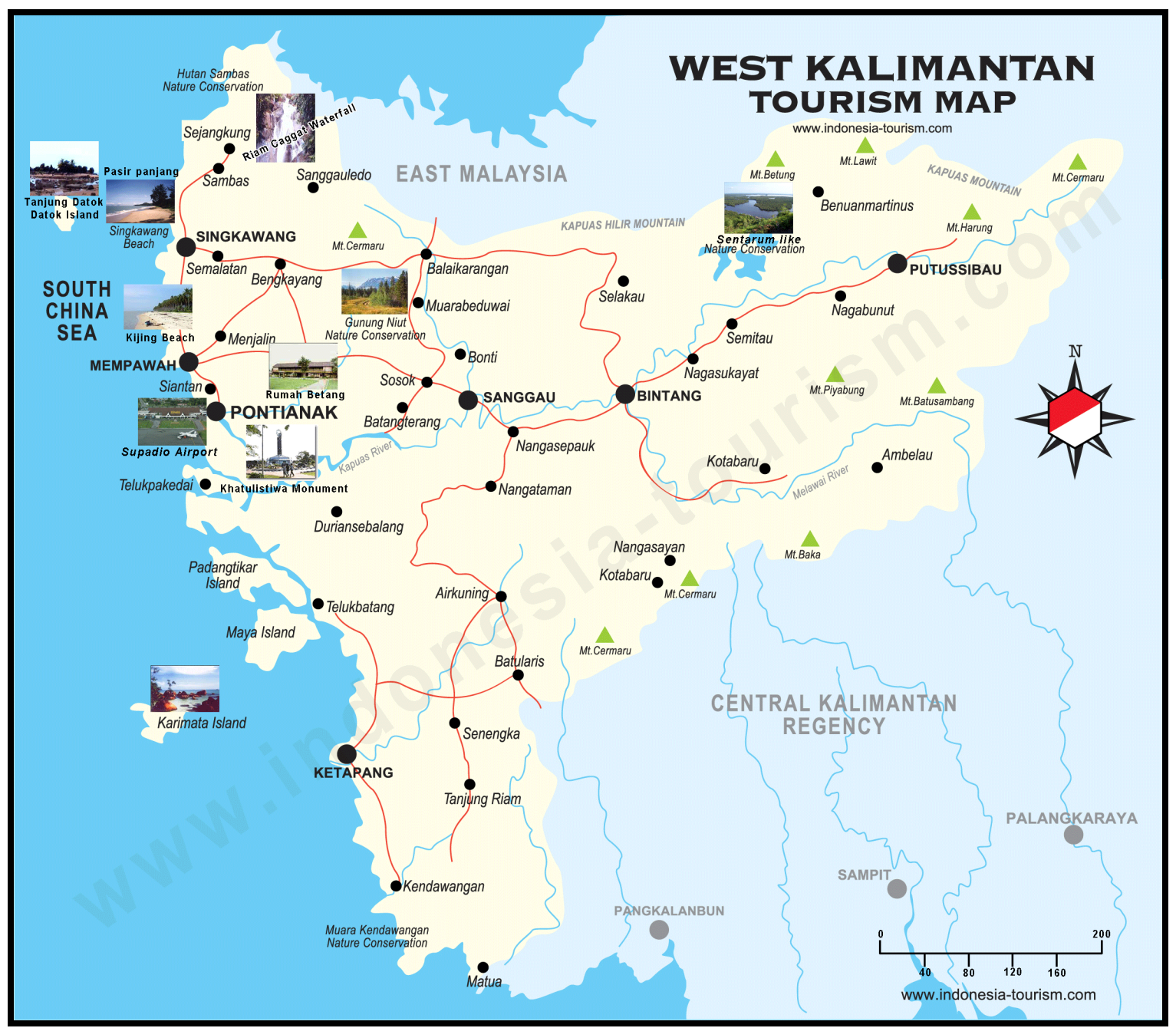

Figure 1. Map of West Kalimantan showing its capital city Pontianak and the town of Sambas in the north (https://junglemaps.blogspot.com/2017/12/map-of-kalimantanbarat.html).

\section{Common features of the Dutch letter with the style of the Malay rulers' letter}

The content of the letter is very interesting because it contains etiquettes of letter writing some having common features with the epistles among the Malay rulers, with some other features contrasted completely.

Some common features are:

1) The writing of a short formulaic heading on top of the page as a kind of statement, that is Qawluluhu Haqq (His word is true), which was similar in format with the letter of Sultan Ahmad I of Terengganu to General Baron van der Capellen in Batavia in 1824 with the heading al nujūm wa l-shamsu wa l-qamar (The stars, the moon and the sun).

2) Kind words of endearment and honorable words of addressing the recipients:

"Adapun akan tanda cinta kasih kita kepada Paduka Pengeran Ratu adalah kita mengirimkan Paduka Pengeran Ratu..." ("Verily as a sign of our affection to Your Majesty, we respectfully submit this epistle to Your Majesty....") 
"Barang disampaikan oleh Tuhan Sarwa Sekalian Alam, apalah kiranya datang kepada Paduka Pengeran Ratu Mangku Negara di Negeri Sambas. Maka dipohonkan atasnya umur panjang dengan sihat selamat yang tiada berkeputusan." ("We beseech God Almighty for a safe deliverance of our epistle to Your Majesty the ruler of Sambas. And we pray to God Almighty for your long life and excellent of health perpetually.")

3) Prayer to the Almighty for the long life and good health of the addressee:

"Shahadan pada akhir satar ini lain tiada hanyalah doa kita mudah-mudahan Paduka Pengeran Ratu beroleh umur panjang dengan sihat selamat sejahtera yang tiada berkeputusan jua adanya." ("As a conclusion of our epistle wee beseech God Almighty for Your Majesty's long life and excellent of health perpetually")

4) The mention of the exchange of precious gifts:

"Dan lagi persembahan Paduka Pengeran Ratu kepada kita jadi tanda tulus ikhlasnya iaitu satu buku air emas sebagaimana didapat dari tanah yang jadi satu ajaib berpatutan berat sembilan belas ringgit lebih tiga emas, itupun kita sudah terima dengan suka hati. Adapun akan tanda cinta kasih kita kepada Paduka Pengeran Ratu adalah kita mengirimkan Paduka Pengeran Ratu satu perangkat perabut minuman kopi dan selai yang berkembangan warna warna." (And Your Majesty's gift of a rare earth lump of gold ingot of nineteen and three gold in weight, was indeed a sign of your sincerity and we did accept it with deepest appreciation. And as a sign of our own affection to Your Majesty we herewith offer you gifts of a complete set coffee maker and jam manufactured in various colours.")

\section{Features of the Dutch letter which contrasted to the Malay Rulers' letter writing styles}

One feature that is in complete contrast with the etiquette of Malay rulers' letter writing is the conspicuous introduction in the opening line of the Governor-General's letter, of the status of the sender with grandeurs mentions of one's honor and awards:

“...daripada kita Sri Paduka yang Dipertuan Besar Minister van Staat Gouverneur Generaal dari Tanah Hindie Nederlands Jan Jacob Rochussen yang terhias dengan Bintang Besar Yang Pertama Bahaduri Singa Nederlands dan Bintang Besar Rajawali Merah dari negeri .. (illegible), dan Bintang Besar dari Maharaja (illegible) di negeri ............... (illegible)... serta lagi menjadi Officer Besar tanda kehormatan dari negeri Francis serta terhias dengan Bintang Besar negeri Brusselle, yang bersemayam di atas takhta kerajaan di Negeri Betawi." ("... from us Excellency the Right Honorable State Minister Governor General of the Dutch East Indies Jan Jacob Rochussen, honored with the Order of the Dutch Lion Knighthood and Order of Red Eagle from...Order of the Emperor.... Also appointed as Chief Officer as a mark of honor from France and also Order from Brusselle, presently enthroned in the State of Batavia.") 
This is in complete contrast with the opening paragraph of the letter of Sultan Ahmad I of Terengganu to General Baron van der Capellen in Batavia in 1824 (appended below), with the mention of sincere intention and purity of heart:

"Bahawa warkah al-wujud hidayat al-mamdûd yang terbit daripada fuad al-zakiah yang amat gilang-gemilang hingga putih jernih bercahaya yang tiada menaruh cemar dalamnya, iaitu daripada Paduka Seri Sulţan Ahmad ibn al-Sulţan Zainal'Ābidin yang di atas takhta kerajaan di dalam negeri Terengganu dengan segala daerah takluknya sekalian." ("This is an epistle of sincere wishes of complete cooperation coming out of our deepest thought of purity and wisdom without any tinge of defection, from us Royal Highness Sultan Ahmad ibn al-Sultan Zainal'Ābidin sitting on the throne of the State of Terengganu and all its territories.")

Another feature of the Dutch Governor-General's letter which contrasted to the Malay rulers' letter writing style was the use of plain paper without illumination, while illumination among Malay letters was a practice with a long tradition, although according to Gallop (1994: 39), little is known about the context and techniques of Malay illuminations. In this context among the beautiful illuminated Malay letters, was perhaps from Sultan Ahmad I of Terengganu to General Baron van der Capellen in Batavia in 1824, mentioned above.

\section{Conclusion}

In this paper a study of a letter written in 1848 by the Dutch Governor-General in Batavia, to a Malay ruler of Sambas, was made in the forms of brief description of its historical background, analysis of its content and styles as compared to the Malay rulers' letter writing styles, and finally a transliteration and annotation of the letter. It is found that four of its features were having similarities with the Malay rulers' letter writing styles, namely short formulaic heading on the top of the page, kind words of endearment and honorable words of addressing the recipients, prayer to the God Almighty for the long life and good health of the addressee, and mentioning of the exchange of precious gifts.

However, two features were in complete contrast with that of the Malay rulers' letter writing style. Firstly, the conspicuous introduction in the opening line of the Governor-General's letter, of the status of the sender with grandeurs mentions of his honor and awards, and secondly was the use of plain paper without illumination, while illumination among Malay rulers' letters was a practice with a long tradition.

This study also revealed that although the letter was from a Dutch Colonial Governor-General to one of the Malay rulers under his dominion, the civility, mutual respect and appropriate decorum of addressing between rulers, were practiced and adopted. An important finding of this study is that this Dutch's government officer's epistle was indeed employing an etiquette of diplomatic parlance between two governments so as to preserve peace and avoid armed conflicts that could bring great loses on both sides. Another important finding was the exchange of gifts between two governments to instill friendship and goodwill. The availability of foreign government letters kept in the treasury of local government were indeed rare because of the destruction of most palace's treasury or due to thefts and robberies. 


\section{Acknowledgement}

We would like to acknowledge with gratitude to the National Library of Malaysia (Perpustakaan Negara Malaysia) especially to the Deputy Director General Mdm. Nasimah Badaruddin, Senior Assistant Director Mr. Faizal Hilmie Yusof and their officers in making available these manuscripts for this study.

\section{Corresponding Author}

ROZITA CHE RODI (PhD) ita_cherodi@upm.edu.my is a Senior Lecturer at the Department of Malay Language, Faculty of Modern Languages and Communication, Universiti Putra Malaysia, 43400 UPM Serdang Selangor, Malaysia, specializing in Semantics: Cultural Semantics and Malay Thought and Civilization.

\section{References}

Karim, A. R. A. (2002). Aspek Penggunaan Bahasa dalam Warkah-Warkah Melayu Lama: Satu Kajian. Kuala Lumpur: Akademi Pengajian Melayu, Universiti Malaya.

Gallop, A. T., \& Arps, B. (1991). Golden Letters: Writing Traditions of Indonesia. London: The British Library.

Gallop, A. T. (1994). The Legacy of the Malay Letter. With an essay by Kratz, E. U. London: The British Library.

Gallop, A. T. (2006). Malay Manuscript Illumination. Jurnal Filologi Melayu, jilid 14, 107-128. Mu'jizah. (2009). Iluminasi dalam Surat-surat Melayu Abad ke-18 dan ke-19. Jakarta: KPG. 


\section{Transliteration and Annotation of The Letter from Gouverneur Generaal Van Nederlands- Indie to Paduka Pengeran Ratu Mangku Negara Negeri Sambas Dated 1264 H / 1848 CE}

.(illegible)... iaitu daripada kita Sri Paduka yang Dipertuan Besar Minister van Staat Gouverneur Generaal dari Tanah Hindie Nederlands Jan Jacob Rochussen ${ }^{2}$ yang terhias dengan Bintang Besar Yang Pertama Bahaduri ${ }^{3}$ Singa Nederlands ${ }^{4}$ dan Bintang Besar Rajawali Merah ${ }^{5}$ dari negeri (illegible), dan Bintang Besar dari Maharaja (illegible) di negeri (illegible)... serta lagi menjadi Officer Besar tanda kehormatan dari negeri Francis serta terhias dengan Bintang Besar negeri Brusselle, yang bersemayam di atas takhta kerajaan di Negeri Betawi. Barang disampaikan oleh Tuhan Sarwa Sekalian Alam, apalah kiranya datang kepada Paduka Pengeran Ratu Mangku Negara di Negeri Sambas. Maka dipohonkan atasnya umur panjang dengan sihat selamat yang tiada berkeputusan. Waba'da kemudian daripada itu kita memberi tahu kepada Paduka Pengeran Ratu darihal suratnya yang tertulis kepada 13 haribulan Sya ban tahun $1264^{6}$ telah sampai kepada kita dengan selamatnya. Dan lagi persembahan Paduka Pengeran Ratu kepada kita jadi tanda tulus ikhlasnya iaitu satu buku ${ }^{7}$ air emas sebagaimana didapat dari tanah yang jadi satu ajaib berpatutan ${ }^{8}$ berat sembilan belas ringgit lebih tiga emas, itupun kita sudah terima dengan suka hati. Adapun akan tanda cinta kasih kita kepada Paduka Pengeran Ratu adalah kita mengirimkan Paduka Pengeran Ratu satu perangkat ${ }^{9}$ perabut minuman kopi dan selai ${ }^{10}$ yang berkembangan warna warna. Shahadan pada akhir satar ${ }^{11}$ ini lain tiada hanyalah doa kita mudah-mudahan Paduka Pengeran Ratu beroleh umur panjang dengan sihat selamat sejahtera yang tiada berkeputusan jua adanya.

Tertulis warqah ini di dalam istana kita di Negeri Betawi kepada 27 haribulan Februari tahun .........(illegible), iaitu $5^{12}$ haribulan Rabi ul Akhir Hijrah $1264^{13}$.

\section{English Translation of The Letter from Gouverneur Generaal Van Nederlands-Indie to Paduka Pengeran Ratu Mangku Negara Negeri Sambas Dated 1264 H / 1848 CE}

(illegible)... from us Excellency the Right Honorable State Minister Governor General of the Dutch East Indies Jan Jacob Rochussen, honored with the Order of the Dutch Lion Knighthood and Order of Red Eagle from... (illegible). Order of the Emperor.... (illegible)... Also appointed as Chief Officer as a mark of honor from France and also Order from Brusselle, presently enthroned in the State of Batavia. May God Almighty deliver this

\footnotetext{
2 Jan Jacob Rochussen was assigned as Governor-General of the Dutch East Indies 1845-1851, and arrived in Batavia in $1845 \mathrm{CE}$.

${ }^{3}$ bahaduri = bintang pingat tanda keberanian, pahlawan $=$ Knighthood

${ }^{4}$ Order of the Dutch Lion as a Knight awarded to Jan Jacob Rochussen on July 4, 1829

${ }^{5}$ Rajawali = burung helang = eagle

6 I r 7 F $1264 \mathrm{H}=1848 \mathrm{CE}$, old Arabic numeral for number $4=\varphi$

${ }^{7}$ buku = bongkah kecil-kecil daripada tanah, batu dll. = lumps of soil, stone, etc.

${ }^{8}$ berpatutan $=$ bersamaan, sama dengan $=$ equivalent

${ }^{9}$ perangkat $=$ selengkap $=$ complete set

${ }^{10}$ selai $=$ (Dutch Indonesian) jem = (English) jam

${ }^{11} \operatorname{satr}($ Ar. $)=$ baris tulisan = written line

$125=\varepsilon$ old Arabic symbol for number 5 (ref. "Origin of the numerals: Al-Biruni's testimony", Ahmed Boucenna, Laboratoire DAC, Department of Physics, Faculty of Sciences, Ferhat Abbas, University 19000 Stif, Algeria.

13 I Y 7F $=1264 \mathrm{H}=1848 \mathrm{CE}$ (ref. Freeman-Grenville, G. S. P. The Islamic and Christian Calendars, pp. 60)
} 
epistle safely into the possession of His Majesty the king of the state of Sambas. And we beseech that Your Majesty will be showered with a long life and an excellent of health. And consequently we wish to inform Your Majesty that your epistle of Sya'ban 13, 1264 was safely delivered into our possession. Moreover, Your Majesty's gifts to us as a sign of sincerity of heart in the form of a rare earth lump of gold ingot of nineteen and three gold in weight, was indeed a sign of your sincerity and we did accept it with deepest appreciation. And as a sign of our own affection to Your Majesty we herewith offer you gifts of a complete set coffee maker and jam manufactured in various colours. As a conclusion of our epistle we beseech God Almighty for your long life and excellent of health perpetually.

This epistle was written in our palace of the State of Batavia on February 27, the year of .... (illegible), that is on the $5^{\text {th }}$ day of the month of Rabi ${ }^{\prime} u l$ Akhir Hijrah 1264. 


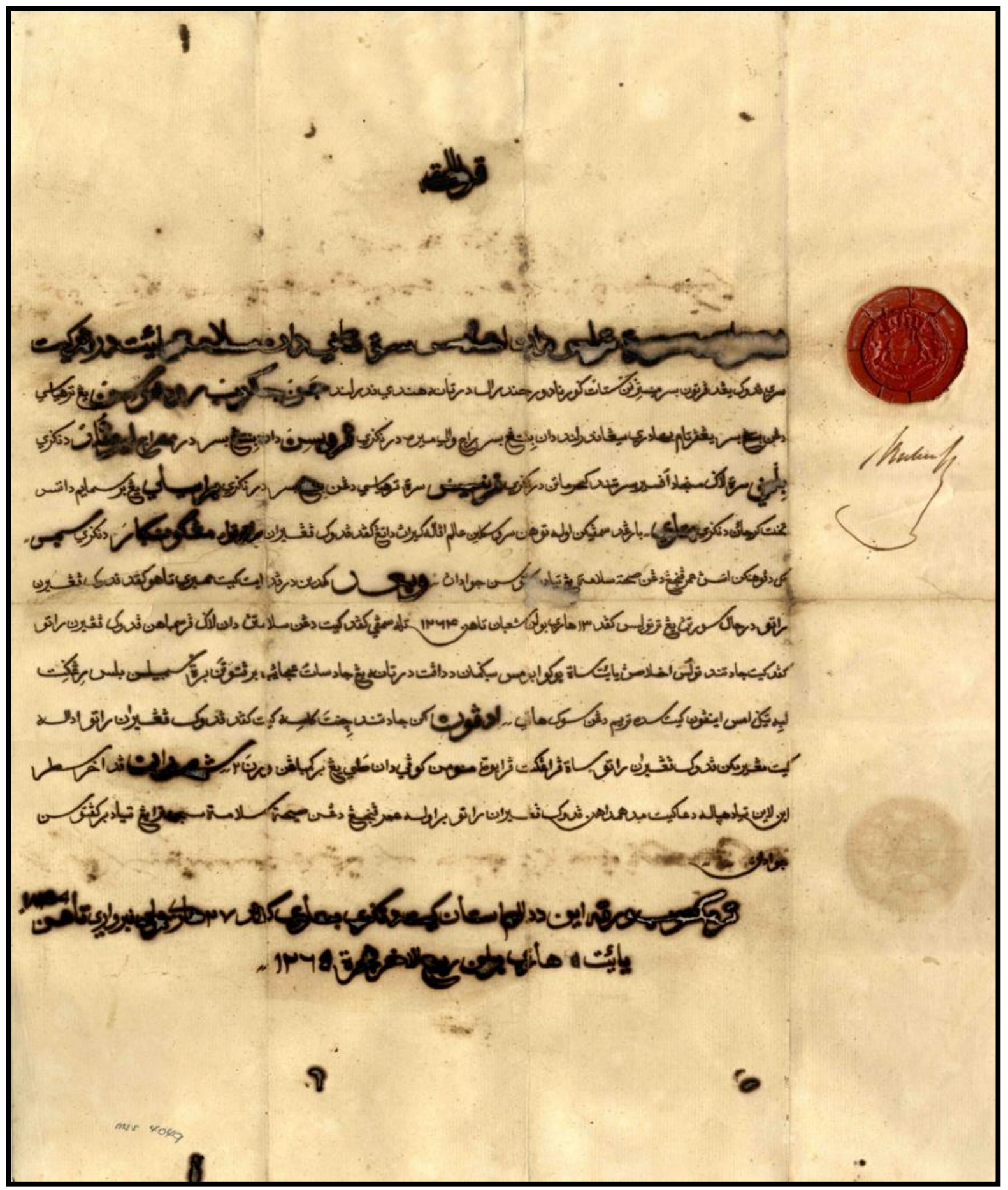

Figure 2. The Letter from Gouverneur Generaal Van Nederlands-Indie to Paduka Pengeran Ratu Mangku Negara Negeri Sambas Dated 1264 H/1848 CE (The National Library of Malaysia). 


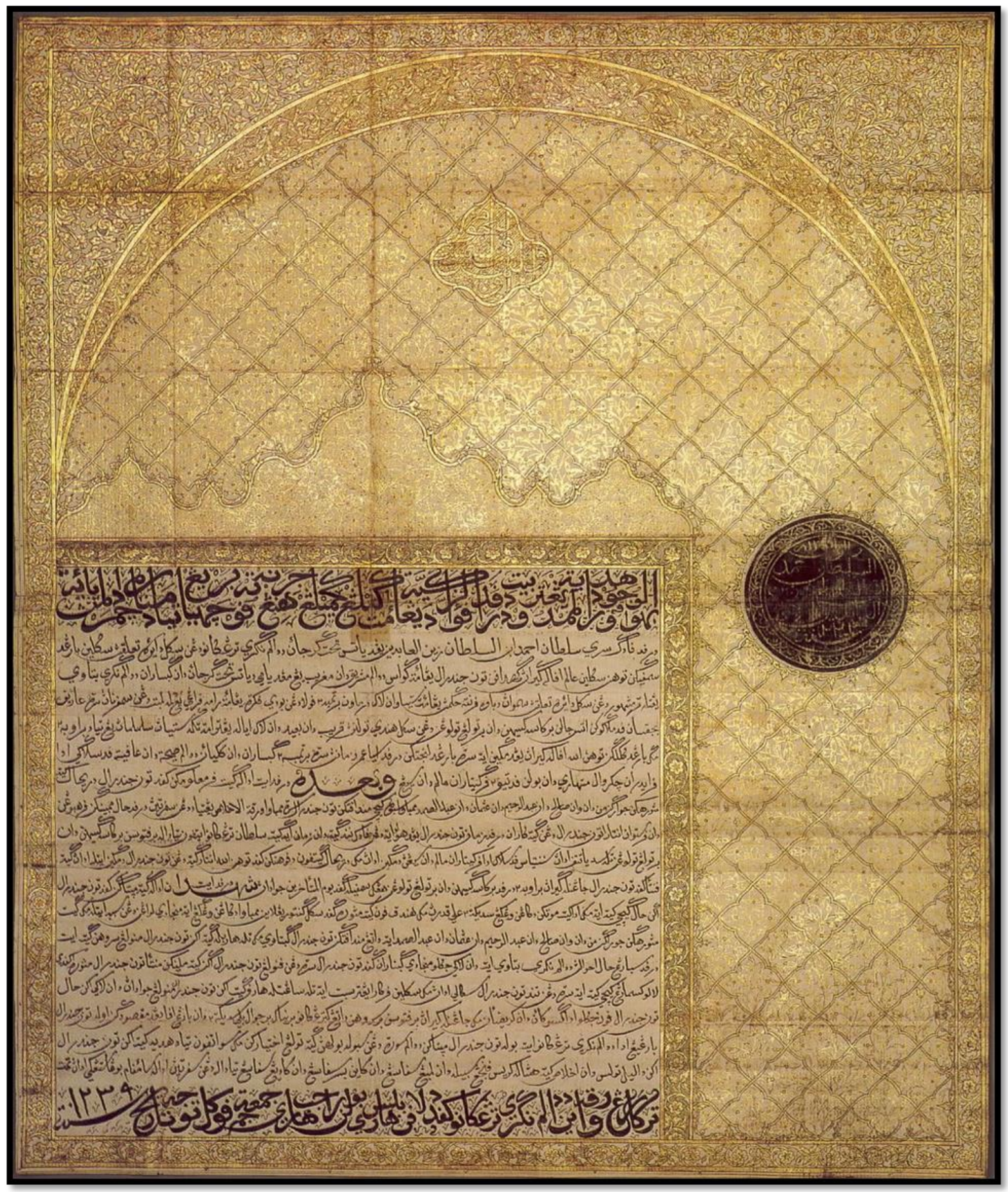

Figure 3. Illuminated letter of Sultan Ahmad I of Terengganu to General Baron van der Capellen in Batavia dated 1239 H = 1824 CE (Gallop, 1994: 39). 